\title{
A Survey of China's Logistics Industry and the Impacts of Transport Delays on Importers and Exporters
}

\author{
ZEYAN ZHANG* AND MIGUEL ANDRES FIGLIOZZI*** \\ *Institute of Transport and Logistics Studies, University of Sydney, NSW, Australia; ${ }^{* *}$ Civil \\ Engineering Department, Portland State University, Oregon, USA
}

(Received 16 May 2008; revised 8 December 2008; accepted 19 February 2009)

\begin{abstract}
In the last decades, China's booming economy has greatly benefited from globalization and trade liberalization. China has found a niche as the world's manufacturing centre and it is playing a crucial role in a growing number of global supply chains. This research focuses on the performance of international and domestic transport and logistics systems as perceived by Chinese importers and exporters. A broad literature review of Chinese meteoric logistics industry development is provided. Results and analysis of in-depth interviews with Chinese importers and exporters are presented. These interviews provide significant information regarding international freight transport chains, the impact of delays on supply chain operations and the subsequent costs, companies' delay and disruption planning, and managers' perspectives on future transport and logistics developments.
\end{abstract}

\section{Introduction}

World merchandise trade growth has outpaced growth of Gross Domestic Product (GDP) since the end of World War II and recently accelerated due to free trade agreements and the globalization of the economy (WTO, 2007). In the last decades, China's booming economy has greatly benefited from globalization and trade liberalization. China has found a niche as the world's manufacturing centre and has become an engine of Asian growth and increased geopolitical importance (Mcgregor, 2006).

China is playing a pivotal role in a growing number of global supply chains. China's main exports destinations are the USA, the European Union (EU), Hong Kong and Japan which represent $68 \%$ of exports by value. Almost $50 \%$ of total imports come from Japan, Korea, Taiwan and the EU. For example, Chinese imports constitute $7.5 \%$ of total spending by Americans on consumer goods and import-wise they comprise $40 \%$ of clothing, $80 \%$ of toys and $85 \%$ of footwear imported to the USA (Barboza, 2008). Growing trade between China and

Correspondence Address: Miguel Andres Figliozzi, Civil Engineering Department, Portland State University, Oregon, USA and Institute of Transport and Logistics Studies, University of Sydney, NSW, Australia. Email: figliozzi@pdx.edu 
developed western countries have not only spurred business opportunities, but also brought growing strains on international and domestic transport networks. This trade surge has also worsened congestion, delays and environmental problems in ports and coastal regions. Given the increasing significance of China as a major trading partner, the purpose of this research is to study international transport and logistics issues as perceived by Chinese managers. In an increasingly global economy, conditions at the origin or exporting country may have an impact on the transport network of the importing country.

This research also explores the impact of transport delays on importer and exporter supply chains. The broad impacts of delays on international supply chains have not been adequately researched in transport and logistics literature. Hence, using in-depth interviews with Chinese logistics managers this research aims at providing a general understanding of the impact of delays on supply chain costs and operations, companies' delay and disruption planning, and future transport and logistics developments from the perspective of decision-makers. A review of key Chinese economic and logistics milestones in the last three decades provides the necessary historical background and context to analyse present managers' responses and perspectives. Section 'China's Logistics Industry Development' presents a review of the history of China's economy and logistics industry from a centralized Marxist economy to a vibrant world manufacturing centre. This section is followed by a review of the main transport and logistics challenges currently faced by Chinese companies. Section 'Data Collection Process' describes the survey and data collection process. Section 'Analysis of Survey Results' presents summary statistics and the analysis of the collected survey data. Section 'Conclusions' ends with conclusions.

\section{China's Logistics Industry Development}

This section summarizes the history of Chinese logistics development in the last three decades. Three periods stand out: a period of centralized economy pre-1978, a period of liberalization between 1978 and China's entrance to the World Trade Organization (WTO) in late 2001 and a recent period of continuing trade and economic growth.

\section{The Centralized Economy}

In the late 1970s, almost 30 years ago, China was a closed planned economy with scant amount of foreign trade. Prior to 1978, 5-year central economic plans designed and approved by the Chinese Communist party ran the economy. The State Planning commission, the Commercial Bureau, the Commercial Office, the City Commercial Office and the Country Commercial Office formulated the state plan and coordinated economic activities including: what, where and how much to manufacture as well as how to allocate and distribute any economic output. The central plan also dealt with the workings of a three-tier distribution system designed and controlled by the governmental bureaucracy.

The three-tier distribution system was established using a top-down approach. Under this distribution system only state-owned wholesalers were allowed to provide logistics service. Wholesalers' major activities were restricted to warehousing and delivery. Three national tier-1 distribution centres were located in 
Tianjin, Shanghai and Guangzhou and 59 national wholesale centres used for national or regional distribution. About 1400 tier-2 distribution centres were located in the provincial capitals and medium-sized cities. Tier-2 centres were responsible for regional distribution, stored and transported products at a provincial level and dealt with distribution to major urban areas. Tier-3 centres operated in smaller cities and towns and provided storage and final delivery to local retailers and small villages. Product flows were strictly controlled and followed a hierarchical system: shipments were moved from state owned factories to tier-1 facilities, then to tier-2 province and city centres and finally to smaller tier-3 cities and towns (Luk, 1998).

Relationships among members within the three-tier distribution system were bureaucratic, that is competitive relationships did not exist within or outside the distribution channel. The bureaucratic position in the system determined the links and flows in the distribution network. From top to bottom, system performance was measured in terms of fulfilment of the central administration goals as well as alignment with the political interests of the ministry (Luk, 1998). Without competition, state-owned distributors were able to keep 5-17\% margins at each layer without offering any value-added and/or logistics service beyond basic transport and warehousing services (Jiang and Prater, 2002). In modern logistics jargon, it was a perfect example of a push supply chain. However, unlike supply chains in competitive markets, in China's centralized economy the satisfaction of consumer needs and demands was not a vital or strategic goal.

\section{Liberalization}

The beginning of China's opening to the world economy and the liberalization of its centralized planning economy took place in the late 1970s. In 1978, the Chinese government initiated the reform of the three-tier distribution system. A new commodity circulation system was established where state-owned enterprises still played a leading role, but the limited participation of private enterprises and workers' cooperatives was not only allowed but also encouraged. In 1984, companies were granted greater autonomy including new financial, planning and operational capabilities. A significant change was the power to set prices over some products and the increased labour flexibility regarding hiring and salary decisions. This greater autonomy gradually allowed both manufactures and commercial enterprises to explore new markets, select suppliers and choose logistics providers and services. In late 1993, further deregulation allowed greater market competition (Luk and Sherriff, 1998; Pyke et al., 2000).

Foreign trade practices also underwent dramatic transformations in the 1980s. Prior to 1978, the rights to import and export any product were reserved by foreign trade corporations (FTCs). Any import or export had to go through FTCs. Domestic and international trade was clearly split. Distributors were prohibited from import or export activities as FTCs were forbidden to commercialize or distribute import products into the domestic market. All imports were required to be handed over to authorized state-owned domestic distributors that were at the top of the three-tier distribution system.

Until mid-1980s, each industrial sector had an official FTC to buy and sell foreign products according to central directives. By the mid-1980s, the central government allowed provinces and large municipalities to regulate and establish FTCs. By the late 1980s, a few domestic enterprises with large trade volume were 
permitted to import and export directly (Baldinger, 1998). In 1993, more domestic distributors and manufacturers were granted greater autonomy to handle import and export operations (CGOWP, 2006). By late 1993, foreign investors were allowed to invest in retail business in certain inland cities and joint ventures were granted more flexibility in selling products to the domestic market (Luk and Sherriff, 1998). Foreign-owned Logistics Service Providers (LSP) were severely regulated until 2001. In particular, aviation, custom brokering, trucking, shipping and freight forwarding were highly regulated by the Civil Aviation Administration, Ministry of Foreign Trade and Economic Cooperation and the Ministry of Communications.

In 2001, a condition for China to become a full member of the WTO was the removal of restrictions to foreign logistics investments. Initially, foreign capital was allowed only in joint ventures where Chinese partner held a majority (Goh and Ling, 2003). Restrictions were completely phased out by the end of 2005. Currently, state-owned, privately/locally owned and foreign-owned logistics companies are all equally allowed to enter and compete in logistics and distribution activities.

\section{Recent and Future Transport Developments}

The first few years of the twenty-first century have been characterized by the fast construction of transport infrastructure. During the 5-year plan 2001-05 significant transport infrastructure has been built including $250000 \mathrm{~km}$ of highways and $24700 \mathrm{~km}$ of expressways. By the end of 2006, the total length of Chinese highway has reached $3457000 \mathrm{~km}$ and $77000 \mathrm{~km}$ of railways (Waters, 2007).

The current 5-year plan (2006-10) has an ambitious agenda and will spend hundreds of billions of dollars over the next 5 years to develop China's roads, river ports and railroads. Major initiatives include the completion of: (1) 14 expressways, including one from Beijing to Hong Kong and Macao; (2) six additional railways for passenger transport, including one between Beijing and Shanghai; (3) five new inter-city railways, including one between Beijing and Tianjin and the upgrading of five existing railways including one between Datong and Qinhuangdao; (4) dredging of a deepwater channel at the mouth of the Yangtze River, the course at the mouth of the Pearl River to the sea, and channel dredging in the Yangtze and Pearl River valleys as well as the BeijingHangzhou canal; (5) expansion of ten airports such as those in Beijing, Shanghai and Guangzhou, relocation of the two airports in Kunming and Hefei, and construction of new airports in central, western and north-eastern China; (6) new pipelines and railroad infrastructure for the transport of coal, imported oil, liquefied gas, iron ore, and containers at 12 seaports including Dalian, Tianjin and Shanghai ports; and (7) new coal transit and storage bases in eastern and southern China (CGOWP, 2006).

\section{Recent Growth Rates}

China's economy has experienced a dramatic and consistent growth since China started its economic reform in 1978. The rate of Chinese economic growth clearly reflects the country's rapid liberalization. China's GDP reported an average of $10 \%$ annual growth rate between 1980 and 2005. According to National Bureau of 
Statistics of China, China's GDP has risen from RMB 362.4 billion in 1978 to RMB 20941 billion in 2006 (equivalent to 2006 US \$2800 billion). In 2006, China achieved the fifth largest GDP in the world after the USA, Japan, Germany and the UK (Johnson, 2007).

China's foreign trade, fuelled by economic reform and accession to the WTO in 2001, has grown at an even faster pace. China's exports tripled from US \$63 billion in 1990 to US \$184 billion in 1998 and again tripled to US \$593 billion by 2004. China's import also achieved quadruple increase from US $\$ 140$ billion in 1998 to US \$561 billion in 2004. According to the WTO, during the decade 19952005 , China experienced an annual growth rate of $18 \%$ in merchandise exports and $17 \%$ in merchandise imports. In 2005, China accounted for about $6.9 \%$ of total world merchandise trade, ranking in third place. In terms of commodities, in $2005,92 \%$ of exports were attributed to the manufacturing industry; imports were dominated by manufactures and components (75\%) followed by fuels and mining products (18\%). In 1999, China's logistics industry reported an annual growth rate of 31\%, 35\% in 2000 and 55\% in 2001 (Bolton and Wei, 2003). Between 1992 and 2004 , the average annual growth rate of the China's logistics industry was $22.2 \%$ and logistics expenditures accounted for an average of $21.8 \%$ of the GDP (Wang et al., 2006).

\section{China's Transport and Logistics Challenges}

This section concisely reviews the large body of literature that has explored Chinese logistics industries' problems and growth challenges. We focus on transport and logistics issues and have summarized them into eight categories:

\section{Low Efficiency and High Logistics Costs}

The astonishing rate of growth in the Chinese economy and foreign trade has not brought about the most efficient logistics industry. Compared with developed countries, the efficiency of China's logistics industry is still low in terms of the ratio of logistics expenditures to GDP. In 2000, China's logistics expenditures amounted to $20 \%$ of the GDP whereas logistics spending accounted for $10.3 \%$ of USA's GDP, 14\% of Japan's GDP and 10-13\% of EU's GDP (Waters, 2007).

Adding the costs of packing, transport, storage and damage, the ratio of total logistics costs to total industry production ranges from $40 \%$ to $60 \%$, whereas in the USA this percentage is close to 20\% (Smyrlis, 2006). If logistics costs are broken down, transport accounts for $57 \%$ of costs, inventory and storage accounts for $29 \%$ and management accounts for $14 \%$. Percentage wise, transport costs in China are twice as expensive as in developed countries (Waters, 2007).

\section{Congestion}

Despite recent efforts to upgrade transport infrastructure, China's transport infrastructure is still insufficient to satisfy the huge demand generated by its booming economy. Congestion and shipments delay are frequent at Chinese seaports due to capacity shortage (Fallows, 2007). Highway construction and transport bottlenecks augment congestion problems in port areas (Goh and Ling, 2003). Archaic infrastructure and lack of adequate highway networks connecting the developed coastal regions to underdeveloped inland provinces increase rail and river 
congestion as more companies are moving inland to take advantage of reduced labour costs (Mongelluzzo, 2007).

\section{Lack of a Nationally Integrated Intermodal Transport Network}

There exists poor communication and coordination between Ministry of Communications, Ministry of Railway and Civil Aviation Administration that regulate highways, railways and airways, respectively (Chung, 2007). A 'super ministry' has recently been proposed to streamline government functions and integrate the country's transport system (CGOWP, 2008). Local regulations also hinder the formation of logistics and transport companies with a complete national network. It is difficult for China's small haulage companies to do business beyond its own regions boundaries due to local protectionism. There are no national trucking firms in China and most trucking companies are small-scale or family-based operators with limited service and rarely travel beyond regional boundaries.

\section{Entrenched Regulation and Local Protectionism}

Despite a reduction in national level regulations since China's entry to the WTO, local governments still set up bureaucratic and political barriers to protect local businesses or products and prevent the entry of outside competitors. Municipal governments also compete to attract logistics hubs and infrastructure. This local protectionism is driven by the desire to maximize local economic growth, employment, social stability and tax revenues, and less by concern about the efficient utilization of regional resources or the creation of an integrated national transport network (Jiang and Prater, 2002). Local interests and economic development have lobbied for, sometimes unnecessarily, the duplication of logistics parks and transport infrastructure in closely located municipalities.

\section{Railways}

Railways cannot alleviate highway congestion in the near future. The capacity shortage in Chinese rail systems is severe and most of the freight capacity is used to transport bulk materials such as coal, steel and iron. Rail in China has not proved competitive for finished goods and industrial products due to long booking times and delays. In 2005, less than $1 \%$ of container throughput at major Chinese ports were moved by a railway service and trucking has been the dominant transport mode for freight due to its reliability and flexibility (Roth et al., 2008). As congestion around ports increases and manufacturing moves inland, China plans to increase the share container movements by intermodal rail from its current $2.6 \%$. The master plan for the China Railway Container Corporation calls for construction of 18 inland rail logistics hubs and the addition of double-stack intermodal service to the major seaports (Mongelluzzo, 2007).

\section{Poor IT Infrastructure and Inability to Use Advance Technology}

China is one of the largest users of mobile and fixed telephone lines and has the second largest number of internet users after the USA. However, some interior and mountainous areas still lack cable and satellite facilities. Frequent blackout and power outages also hinder logistics development and the modernization of 
corporate information technology (IT) systems. The absence of web-enabled tools and know-how is affecting Chinese companies' international competitiveness. IT development is regarded as one of the top challenges for China's logistics sector (Goh and Ling, 2003).

\section{Underdeveloped Warehousing Service}

Most of China's warehouses were built as single-storey brick structures with low ceilings, poor lighting, no or inadequate sprinklers, poor temperature control devices and poor dock levelling. The percentage of food and perishable goods spoiling is thus high overall due to the lack of controlled temperature warehouses and unskilled management. Manual labour is still utilized because it is abundant and less expensive than the application of automated warehousing facilities and the cost of training personnel. Assembling in warehousing is rare and most order picking and packing are still done manually.

Ports

Approximately 90\% of China's international trade volume is handled through maritime transport. Increased trade volumes, heavy investments in port infrastructure and intense competition between ports have lead to the emergence of highly efficient ports that may easily outshine the productivity of many European and North American ports (Cullinane et al., 2004; Song and Yeo, 2004; Yap et al., 2006; Comtois and Dong, 2007). According to the National Bureau of Statistics of China, annual container traffic added up to 93 million twenty-foot equivalent unit containers (TEU) in 2006. This is an increase of 151\% compared with 37 million TEU moved in 2002 and represents an annual growth rate of $26 \%$. Although port productivity is not an issue, Chinese ports are affected by inadequate intermodal connections, bureaucratic custom procedures and in some cases low customer service (Song and Yeo, 2004).

Companies closely located to ports are significantly less affected by the transportation and logistical challenges as described in the above subsections. The high logistics costs described in subsection 'Low Efficiency and High Logistics Costs' are more typical of inland companies. Assembly or manufacturing companies located in coastal areas tend to have lower logistics costs as detailed in Section 'Analysis of Survey Results'.

\section{Data Collection Process}

The previous sections have highlighted key developments related to China's impressive economic success as well as problems that affect the performance of the transport and logistics sector. This section describes the data collection process that was undertaken to study the performance of international and domestic transport and logistics systems as perceived by Chinese importers and exporters.

Chinese companies were carefully selected to ensure that a wide range of products and industries were represented in the in-depth interviews. Given the fast growth and high mobility of the manufacturing sector in the Shenzhen region, official statistics are non-existing or at best outdated and inaccurate. In addition, there is a strong informal economy that is not captured by official statistics. 
Without a reliable census of economic activity, it is difficult to design a traditional sampling strategy. In this environment, the sampling approach used in this research was to conduct interviews with a diverse group of companies that covered the most important industrial sectors that dominate the Chinese international trade market: manufacturing of electronics, appliances, electrical machinery, consumer products, textiles, chemicals and construction products.

A substantial number of pre-interview telephone calls were carried out to collect general company information and to ensure that the interview would be conducted with a manager that had authority over the company shipping decisions as well as knowledge regarding the supply chain constraints imposed by customer demands or manufacturing/distribution activities. As a general indication, approximately $10 \%$ of the phone calls resulted in a successful interview where the data was included in the results presented in Section 'Analysis of Survey Results'.

The data collection process was painstaking and time consuming in part due to China's business culture. China has very strong cultural practices such as the concept of 'Guanxi' that can be loosely defined as a kind of social relationship or connection. In China, all companies seek Guanxi with their potential partners before they can carry out any business (Lee and Humphreys, 2007). For this research, it was also indispensable to cultivate Guanxi with companies and interviewees before arranging face to face interviews. The importance of having a native speaker with knowledge of the logistics industry conducting the pre-interview telephone calls and face to face interviews cannot be overemphasized in the Chinese cultural context.

The interviews were conducted in Shenzhen, the manufacturing hub of the Pearl River Delta in Guangdong province (the old Canton region), just north of Hong Kong. Guangdong province has a manufacturing workforce larger than the whole USA' manufacturing workforce of 14 million workers. Shenzhen is one of the best examples of the impact of liberalization and foreign trade growth in China. In the early 1980s, Shenzhen was declared a special economic zone where materials and machinery coming in and exports going out would be exempt from the usual duties or taxes. From being a small fishing town of 70 000-80 000 people in the 1980s, Shenzhen's population has grown at least a hundred-fold in the past 25 years (Fallows, 2007).

The sample is representative of companies located in coastal areas rather than inland companies. To provide an indication of the proximity between companies and ports, the median inland transport cost was US \$200 for exporters (door-toport) and US \$225 for importers (port-to-door). For both importers and exporters, typical port-to-door and door-to-port costs ranged from US \$100 to US \$500. Approximately $78 \%$ of the exporters sold using FOB (free on board) terms; approximately $62 \%$ of the importers bought using CIF (cost-insurance-freight) terms.

The median port-to-port costs per FEU or forty-foot equivalent unit, varied widely by destination: on one extreme Japan was the lowest with US \$400 per FEU and Africa (Nigeria) was the highest at US \$2800 per FEU. The median portto-port export costs per FEU to Los Angeles were US \$1600. In comparison, Drewry's container rate benchmark for Hong Kong to Los Angeles was around US \$1700 per FEU at the time of the survey (Drewry, 2007). Thus, the relative cost of inland transport varies with the final destination and the proximity of the importer-exporter to a port. 
A computer aided personal interview (CAPI) software designed and tailored specifically for this research was utilized. The software allowed for a systematic data collection process and ensured the integrity and completeness of the data. The interview was designed to obtain qualitative data regarding supply chain operations and transport decisions as well as information about containerized import or export shipments, delays/disruptions, logistics costs and transit times. Most interviews lasted, on an average, $1 \mathrm{~h}$. A total of 49 managers were interviewed during several months starting in mid-2007. Given China's positive foreign trade account balance a majority of exporters was sought; $71 \%$ of the surveyed companies were exporters and $29 \%$ were importers.

The breakdown per industry and product roughly reflects the composition of Chinese foreign trade. The highest percentage of interviewees was related to the manufacturing of electrical products $(27 \%)$, followed by electronics $(16 \%)$, chemicals $(10 \%)$, mechanical products/appliances $(8 \%)$, raw materials $(8 \%)$, consumer products $(8 \%)$, textile $(6 \%)$ and construction products $(6 \%)$. The remainder $(11 \%)$ included home appliances, ceramics, automotive components and furniture. The official organizational title of the interviewees' were varied and included general manager (and general manager of Chinese branch), sales manager (or marketing department manager), director, assistant director, shipping department manager, planning and logistics manager, customer representative, operations manager, global sourcing manager, international trade manager, purchasing manager, business department manager, import section manager, export manager, purchasing supervisor, vendor account manager, president and chairman.

The interviewed companies' annual sales ranged from US $\$ 500,000$ to US $\$ 3.5$ billion with a median of US $\$ 5$ million. TEU volumes shipped by sea ranged from a few dozens to the maximum of 8 million containers per year with a median of 300 containers per year. In terms of container value, the range was from US \$1500 for raw materials to a maximum of US \$200 000 for high-tech electronics. The data and analysis presented in the following Section 'Analysis of Survey Results' is based on in-depth interviews with supply chain managers based in Shenzhen.

\section{Analysis of Survey Results}

The focus of the in-depth interviews was on international trade and the performance of the transport system in relation to export and import movements. As mentioned in Section 'Data Collection Process', the interviews targeted companies are located in the coastal areas surrounding the port of Shenzhen. As discussed in subsection 'Ports', importers and exporters located in coastal areas are less affected by the transportation and logistics challenges associated with inland transportation and distribution chains. Hence, the survey results are dominated by the transportation and logistical issues associated with international trade. Interviewees overwhelmingly ranked freight rates, transit time and reliability as the key transport performance indicators as shown in Table 1. In Table 1, the first row adds up to $100 \%$ as it includes the results of the respondents' first choice; the second row adds up to $200 \%$ as it includes the results of the respondents' first and second choice and so on for the remainder of the rows.

Managers were also asked to identify the causes of and consequences of low transport performance. The following subsections synthesize the results of the interviews in regards to: (1) customs and regulations; (2) weak links in the transport chain; (3) the impact of delays on supply chain costs and operations; and (4) 
Table 1. Ranking of transportation attributes influencing decision-making

\begin{tabular}{lccccc}
\hline & Freight rate (\%) & Transit time (\%) & Reliability (\%) & Damage rate (\%) & Frequency (\%) \\
\hline Rank 1 & 34.7 & 32.7 & 22.4 & 8.2 & 2.0 \\
Rank 1-2 & 67.3 & 71.4 & 36.7 & 16.3 & 8.2 \\
Rank 1-3 & 83.7 & 79.6 & 65.3 & 24.5 & 46.9 \\
Rank 1-4 & 93.9 & 98.0 & 89.8 & 40.8 & 77.6 \\
Rank 1-5 & 100.0 & 100.0 & 100.0 & 100.0 & 100.0 \\
\hline
\end{tabular}

managers' perspectives on the future performance of the Chinese transport and logistics systems.

\section{Customs and Regulations}

The in-depth interviews validated all of the domestic problems already identified in Section 'China's Transport and Logistics Challenges'. In particular, the lack of advanced technology, entrenched regulation and local protectionism, and growing congestion were emphasized by the managers. The growth of in-port capacity has kept pace with demand and ports were not mentioned as bottlenecks; however, a majority of interviewees indicated regulatory and administrative problems that affected port-related activities such as customs operations and also changes in export rebate policies.

Over $85 \%$ of the interviewees cited that good relationships with customs officials and local power brokers/custom agencies are vital to ensure fast custom clearings and to avoid a high number of inspections. A key attribute when choosing carriers is a high reputation in terms of customs handling and relationships. Custom regulations and guidelines are often ambiguous. Custom officials use their experience to check declarations and inspection orders can be issued almost arbitrarily. Several managers also indicated that inspections not only cause delays but can also increase cargo damage and losses.

Adjustments to export rebate policy create congestion at ports, as indicated by $83 \%$ of the interviewees. When the Chinese government reduces the export tax rebate exporters rush to beat the deadline thus creating congestion; this occurred four times between September 2006 and July 2007. Most exporters explained that for products with profit margins, that is in the order of $4 \%-5 \%$, an export tax rebate is a major component of the final profit.

\section{Delays in the Transport Chain}

Managers were asked to rank what leg of the import or export movement was most likely to cause delays. As shown in Table 2, the main cause of delay (as indicated by Rank 1) does not originate in anyone transport leg but rather is caused by an assortment of 'other factors', for example manufacturing, customs, weather or supplier-related delays. Among transport-related delays, transhipment was the highest ranked followed by delays at the loading and discharge port, respectively. Delays that originated in the long haul journey at sea were ranked as the least likely to take place. In Table 2, the first row adds up to $100 \%$ as it includes the results of the respondents' first choice; the second row adds up to $200 \%$ as it includes the results of the respondents' first and second choice. 
Table 2. Ranking of delays by type of transport activity

\begin{tabular}{lccccccc}
\hline $\begin{array}{l}\text { Transport } \\
\text {-related } \\
\text { delay } \\
\text { factors }\end{array}$ & $\begin{array}{c}\text { Delay by } \\
\text { land } \\
\text { transport in } \\
\text { country of } \\
\text { origin (\%) }\end{array}$ & $\begin{array}{c}\text { Delay by } \\
\text { activities } \\
\text { related to } \\
\text { loading } \\
\text { port (\%) }\end{array}$ & $\begin{array}{c}\text { Delay by } \\
\text { transport of } \\
\text { products by } \\
\text { sea (\%) }\end{array}$ & $\begin{array}{c}\text { Delay by } \\
\text { transhipment } \\
(\%)\end{array}$ & $\begin{array}{c}\text { Delay by } \\
\text { activities } \\
\text { related to } \\
\text { discharge } \\
\text { port (\%) }\end{array}$ & $\begin{array}{c}\text { Delay by land } \\
\text { transport in } \\
\text { country of } \\
\text { destination } \\
(\%)\end{array}$ & $\begin{array}{c}\begin{array}{c}\text { Delay by } \\
\text { other } \\
\text { factors } \\
(\%)\end{array} \\
\text { Rank 1 }\end{array}$ \\
Rank 1-2 & 18.1 & 14.3 & 0.0 & 18.4 & 14.3 & 0.0 & 49.0 \\
Rank 1-3 & 40.8 & 36.7 & 4.1 & 40.8 & 26.5 & 12.2 & 61.2 \\
Rank 1-4 & 65.3 & 91.8 & 16.3 & 55.1 & 38.8 & 18.4 & 63.3 \\
Rank 1-5 & 83.7 & 95.9 & 24.5 & 89.4 & 57.1 & 32.7 & 67.4 \\
Rank 1-6 & 100.0 & 100.0 & 49.0 & 98.0 & 81.6 & 53.1 & 69.4 \\
Rank 1-7 & 100.0 & 100.0 & 100.0 & 100.0 & 100.0 & 85.7 & 69.4 \\
\hline
\end{tabular}

Exporters and importers provided similar rankings, however, delays by activities related to loading port scored significantly higher for exporters whereas delays by activities related to discharge port scored significantly higher for importers.

If responses are broken down based on the value of the product per container more differences seem to arise. A threshold of US $\$ 50000$ per TEU was employed to separate low and high value products. High value products show a higher percentage of delays that originate at manufacturing or supplier levels, that is not transport-related delays. Interviews also indicated that high value shippers prefer direct services from Shenzhen and less transhipment. Direct routes that avoid transhipment ports have shorter transit times and less probability of delays. It was also indicated that low value products have a lower priority at the loading ports, which is reflected in the higher percentage of delays at loading port for these products (see Table 3). However, using a chi-square statistical test, the null hypothesis of homogeneity between the populations of high value and low value products is accepted at $90 \%$ significance level. Hence, the chi-square test indicates that similar delays affect low value products. In a great part, this statistical result is determined by the high percentage of delays that originate at manufacturing or supplier levels.

Table 3. Ranking of delays by type of transport activity and product value

\begin{tabular}{|c|c|c|c|c|c|c|c|}
\hline $\begin{array}{l}\text { Transport } \\
\text {-related } \\
\text { delay } \\
\text { factors } \\
(\%)\end{array}$ & $\begin{array}{l}\text { Delay by } \\
\text { land } \\
\text { transport in } \\
\text { country of } \\
\text { origin }(\%)\end{array}$ & $\begin{array}{c}\text { Delay by } \\
\text { activities } \\
\text { related to } \\
\text { loading } \\
\text { port }(\%)\end{array}$ & $\begin{array}{c}\text { Delay by } \\
\text { transport } \\
\text { of } \\
\text { products } \\
\text { by sea }(\%)\end{array}$ & $\begin{array}{c}\text { Delay by } \\
\text { transhipment } \\
(\%)\end{array}$ & $\begin{array}{c}\text { Delay by } \\
\text { activities } \\
\text { related to } \\
\text { discharge } \\
\text { port }(\%)\end{array}$ & $\begin{array}{c}\text { Delay by land } \\
\text { transport in } \\
\text { country of } \\
\text { destination } \\
(\%)\end{array}$ & $\begin{array}{c}\text { Delay by } \\
\text { other } \\
\text { factors } \\
(\%)\end{array}$ \\
\hline \multicolumn{8}{|c|}{ Low value goods } \\
\hline Rank 1 & 2.6 & 17.9 & 0.0 & 20.5 & 12.8 & 0.0 & 46.2 \\
\hline Rank 1-2 & 18.4 & 39.5 & 2.6 & 44.7 & 26.3 & 7.9 & 60.6 \\
\hline \multicolumn{8}{|c|}{ High value goods } \\
\hline Rank 1 & 10.0 & 0.0 & 0.0 & 10.0 & 20.0 & 0.0 & 60.0 \\
\hline Rank 1-2 & 10.0 & 30.0 & 10.0 & 30.0 & 30.0 & 30.0 & 60.0 \\
\hline
\end{tabular}




\section{The Impact of Delays on Supply Chain Costs and Operations}

Managers were asked to describe the type of costs associated with transportrelated supply chain delays and disruptions; lost sales was a ubiquitous answer. In all cases, delays were clearly associated with severe damage to a company's image, reputation and customer relationships. However, when asked about specific costs generated by delays and disruptions, the answers provided by importers and exporters were distinct, as shown in Table 4.

Exporters indicated that delays may force them to offer price discounts, rebates or penalty payments. Longer delays may even result in the cancellation of orders, the return of cargo or the auction of the shipment at foreign ports. Exporters also showed more concern in relation to transport cost increases due to rerouting or mode changes. Contractual and payment terms have a significant impact on exporters' cash flows when delays take place. As expected, exporters selling EX-WORK or FOB origin were not concerned about cash flow impacts. Using a chi-square statistical test with the interviewee's first choice, the null hypothesis of homogeneity between the populations of exporters and importers can be rejected at a $10 \%$ significance level. Hence, the chi-square test indicates that supply chain transport delays and disruptions may possibly affect importers and exporters in dissimilar ways.

Among importers, wholesalers were highly concerned about company reputation, service level and long-term relationships with their retailers. Higher administrative costs related to customer service, communication, documentation and tracking were highlighted by wholesalers. Wholesales and manufacturers that import supplies and raw material were also concerned about higher inventory costs caused by longer lead times. In general, importers also showed a higher concern about the impact of delays on promotions and sales plans as well as costs associated to custom procedures and inspections.

The results of Table 5 illustrate companies' responses to a specific delay or disruption at an operational level. The most prevalent contingency measure to respond to actual delays includes the use of alternative shipping routes, for example, using more direct line shipping instead of indirect line to avoid transhipment delays or expediting the shipment using air or inland trucking to alternative ports. A second major response to tackle delays and disruptions was communication to supply chain parties to reschedule delivery times or speed up processing times. In case of a major delay or disruption, managers indicated that when possible they would tap into their network of alternative suppliers, negotiate customer discounts or rebates and apply late delivery penalties.

As shown in Table 5, little difference was observed between exporters and importers. Using a chi-square statistical test with the interviewee's first choice, the null hypothesis of homogeneity between the populations of exporters and

Table 4. Costs of supply chain transport delays and disruptions

\begin{tabular}{lcc}
\hline Supply chain disruption-related costs & Importers (\%) & Exporters (\%) \\
\hline Increase administration workload and costs & 42.9 & 28.6 \\
Increase transport costs & 28.6 & 37.1 \\
Affect sales and promotion plans & 35.7 & 20.0 \\
Inventory costs & 28.6 & 2.9 \\
Account receivable and cash flow & 0.0 & 12.2 \\
Custom-port costs (inspection, storage, clearance, etc.) & 7.1 & 2.9 \\
\hline
\end{tabular}


Table 5. Contingency plans for delays at an operational level

\begin{tabular}{lcc}
\hline Contingency plans & Importers (\%) & Exporters (\%) \\
\hline Change shipping schedule/route & 50.0 & 45.7 \\
Communication to all parties to reschedule delivery time & 35.7 & 45.7 \\
Alternative sourcing/substitute product & 28.5 & 25.7 \\
Negotiate price discount/rebate to customers_apply penalty & 7.1 & 11.4 \\
to suppliers & & 2.0 \\
Prioritize old/major customers' orders & 0.0 & 2.9 \\
\hline
\end{tabular}

importers is accepted at $90 \%$ significance level. Hence, the chi-square test indicates that contingency plans for importers and exporters show more similarities than differences.

All interviewees declared that they already have contingency plans to handle delays and disruptions at an operational level (results in Table 5). However, at a strategic level only $20 \%$ of the respondents mentioned long-term measures to deal with travel time variability. Long-term measures included lengthening estimated lead times, increasing safety stocks and diversifying the network of carriers and suppliers.

\section{Perspectives on China's Future Logistics Challenges}

In the final part of the interview, managers were asked about their perspectives on the future performance of Chinese transport and logistics systems. Managers indicated that several macroeconomic and international forces are compelling Chinese companies to improve logistical operations. Among the forces cited by the managers three stood out: 'go west' policies, regional imbalances and higher labour costs in coastal areas. These three factors are somewhat interrelated and as a result lengthen supply chains. Given the high logistics costs as percentage of GDP, longer supply chains will exacerbate the logistics costs of operating inland. Managers also indicated that the continuous appreciation of the Yuan against the US\$, an increase of $18 \%$ between 2005 and 2008, and lower export rebates are forcing companies to cut logistics and labour costs in order to remain globally competitive.

Managers indicated that increasing trade volumes between coastal regions and inland provinces result in transport capacity shortages in the coastal regions. Higher transport costs arise due to the high percentage of empty backhauls trips to the inland provinces, the impact of regional imbalances on low cost 'family' or smallscale trucking companies, and legislation that protects regional and small to medium transport and logistics companies. Almost $88 \%$ of managers claimed that labour shortage in Southern China and increases in labour are significantly affecting production costs. Managers also cited that China government's 'go west' campaign and the elimination of agricultural taxes provides extra incentives for worker to remain in farming and creates more job opportunities in inland provinces. As opportunities grow in the west it is harder to attract workers to expensive coastal regions.

\section{Conclusions}

The objective of this research was to survey the Chinese perspective on international freight transport chains, the impact of delays on supply chain costs and 
operations, companies' delay and disruption planning and future transport and logistics planning from the perspective of decision-makers in the supply chain field. Importers and exporters identified transit time and reliability as key transport performance indicators; however, the impacts of delays clearly differ for importers and exporters and by the contractual conditions of delivery and supply chain characteristics. The results of the 49 company interviews in Shenzhen suggest an industry lacking in advance technology, entrenched in regulation and local protectionism, and increasingly impacted by growing congestion, which in turn is having a significant impact on the competitiveness of Chinese companies in the global market.

The growth in port capacity has kept pace with demand and ports were not mentioned as major bottlenecks despite regulatory and administrative burdens. However, as expensive and scant labour in coastal regions force companies to move west the lack of a reliable national freight transport network will affect the competitiveness of Chinese exporters.

The development of a nationwide intermodal containerized rail network and improvements along the Yangtze River are expected to improve transport performance and costs between coastal and inland regions. The fluvial and rail alternative may be able to ameliorate the higher transport costs due to the high percentage of empty backhauls, the high cost of family or small-scale trucking companies and bureaucratic protection of local employment sources. Highly developed manufacturing coastal areas closely linked to modern and efficient ports are not as affected as inland locations by the relative inefficiencies of China's logistic industry.

Congestion and higher logistics costs will increasingly affect companies that move westward to tap into cheaper and more abundant sources of labour and offset the effects of a stronger Yuan. In this survey, for a typical FEU export movement from a coastal area to Los Angeles, door-to-port costs were $11 \%$ of the total cost door-to-foreign port. For intra-Asian movements, to Japan or India, these percentages were higher and ranged from $35 \%$ to $25 \%$, respectively. For companies located inland these percentages will certainly be higher; however, the impact of additional inland transport costs will be smaller when there is a long and expensive port-to-port movement.

Regional imbalances between developed coastal economies and poor inland provinces hinder companies' expansion plans; this is especially true for high value shippers. The appeal of lower labour costs in the Chinese West can be quickly overshadowed by poor infrastructure, longer lead times, frequent delays and limited availability of closely located suppliers. Moving inland will also have financial implication as extended lead times will affect exporters cash flows. This is compounded by contracts moving from EX-WORK to CIF in the Pearl River delta region (Huddersfield, 2008). Service level, company reputation, loss sales, cash flow and safety stock considerations will increasingly affect mode and carrier choice as companies move inland.

Interviewees overwhelmingly identified freight rates, transit time and reliability as the key transport performance indicators. They also indicated that these measures are increasingly affecting their mode and carrier decisions. At the expense of higher freight rates, high value shippers tend to choose direct routes and avoid unnecessary transhipments which results in an overall better transport service with reduced transit times and probabilities of delays. Time and reliability considerations are likely to have an even greater effect as companies move inland. 
Importers and exporters identified transit time and reliability as key transport performance indicators, the impacts of delays clearly differ for importers and exporters and by the contractual conditions of delivery and supply chain characteristics.

The interviews also revealed the complexity of international trade and the many implications of low transport performance on supply chain operations and the subsequent costs. Most of the literature has focused on the identification of attributes and estimation of values of time and reliability in freight transport (Shinghal and Fowkes, 2002; Bergantino and Bolis, 2008). Future research efforts should look towards attempting to quantify the impacts of delays and disruptions on importers and exporters' supply chain operations.

\section{Acknowledgements}

The authors would like to acknowledge Andrew Collins and John Rose at the Institute for Transport and Logistics, University of Sydney, for their assistance in the development of the CAPI software. However, any responsibility for errors or omissions in the final version of this paper rests entirely with the authors.

\section{References}

Baldinger, P. (1998) Secrets of the Supply Chain. China Business Review, 25, p. 8.

Barboza, D. (2008) China's inflation hits American price tags. New York Times, Business Section, 1 February. Available at: http:/ /www.nytimes.com/2008/02/01/business/worldbusiness/01inflate. html?fta=y (accessed 1 February 2008).

Bergantino, A. S. and Bolis, S. (2008) Monetary values of transport service attributes: Land versus maritime ro-ro transport: An application using adaptive stated preferences. Maritime Policy and Management, 35, pp. 159-174.

Bolton, J. M. and Wei, Y. (2003) Distribution and logistics in today's China. China Business Review, 30, p. 8.

CGOWP. (2006) China's key transport infrastructure projects for 2006-2010. Available at: http:// english.gov.cn/2006-03/06/content_219886.htm (accessed 13 March 2008).

CGOWP. (2008) Highlights of institutional restructuring plan. Available at: http://english.gov.cn/200803/15/content_921525.htm (accessed 17 March 2008).

Chung, O. (2007) Hong Kong SMEs withdraw from Mainland China. Asia Times Online, 6 June. Available at: http:/ /www.atimes.com/atimes/China_Business/IF06Cb01.html (accessed 10 June 2007).

Comtois, C. and Dong, J. (2007) Port competition in the Yangtze River Delta. Asia Pacific Viewpoint, 48, pp. 299-311.

Cullinane, K., Fei, W. T. and Cullinane, S. (2004) Container terminal development in Mainland China and its impact on the competitiveness of the port of Hong Kong. Transport Reviews, 24, pp. 33-56.

Drewry. (2007) Container rate benchmark, Drewry shipping consultants. Journal of Commerce, 8(32), August 2007.

Fallows, J. (2007) China makes, the world takes. The Atlantic Monthly, July-August, pp. 48-72.

Goh, M. and Ling, C. (2003) Logistics development in China. International Journal of Physical Distribution and Logistics Management, 33, pp. 886-917.

Huddersfield, U. K. (2008) Evaluation of factors for carrier selection in the China Pearl River delta. Maritime Policy and Management, 35, pp. 27-52.

Jiang, B. and Prater, E. (2002) Distribution and logistics development in China: The revolution has begun. International Journal of Physical Distribution and Logistics Management, 32, p. 783.

Johnson, J. C. (2007) China: A sleeping giant arises; Implications for U.S. logisticians. Journal of Transportation Law, Logistics, and Policy, 74, p. 11.

Lee, P. K. C. and Humphreys, P. K. (2007) The role of Guanxi in supply management practices. International Journal of Production Economics, 106, pp. 450-467.

Luk, S. (1998) Structural changes in China's distribution system. International Journal of Physical Distribution and Logistics Management, 28, pp. 44-67. 
Mcgregor, R. (2006) The trillion dollar question: China is grappling with how to deploy its foreign exchange riches. Financial Times, 25 September. Available at: http://www.ft.com/cms/s/0/ 35ee4216-4c32-11db-90d2-0000779e2340.html?nclick_check=1 (accessed 20 June 2007).

Mongelluzzo, B. (2007) How the west will be won. Journal of Commerce, 22 October, pp. 10-12.

Pyke, D., Robb, D. and Farley, J. (2000) Manufacturing and supply chain management in China: A survey of state-, collective-, and privately-owned enterprises. European Management Journal, 18, pp. 577-589.

Roth, A. V., Tsay, A. A., Pullman, M. E. and Gray, J. V. (2008) Unraveling the food supply chain: Strategic insights from China and the 2007 recalls. Journal of Supply Chain Management, 44, pp. 22-39.

Shinghal, N. and Fowkes, T. (2002) Freight mode choice and adaptive stated preferences. Transportation Research Part E-Logistics and Transportation Review, 38, pp. 367-378.

Smyrlis, L. (2006) Dancing with the dragon (cover story). Canadian Transportation and Logistics, 109, pp. 22-30.

Song, D. W. and Yeo, K. T. (2004) A competitive analysis of Chinese container ports using the analytic hierarchy process. Maritime Economics and Logistics, 6, pp. 34-52.

Wang, Q., Zantow, K., Lai, F. and Wang, X. (2006) Strategic postures of third-party logistics providers in Mainland China. International Journal of Physical Distribution and Logistics Management, 36, p. 793.

Waters, D. (2007) Global logistics new directions in supply chain management, (London/Philadelphia: Kogan Page).

WTO. (2007) Trade statistics. Available at: http://stat.wto.org/CountryProfile/WSDBCountryPFView.aspx?Language=E\&Country=CN (accessed 12 September 2007).

Yap, W. Y., Lam, J. S. L. and Notteboom, T. (2006) Developments in container port competition in East Asia. Transport Reviews, 26, pp. 167-188. 